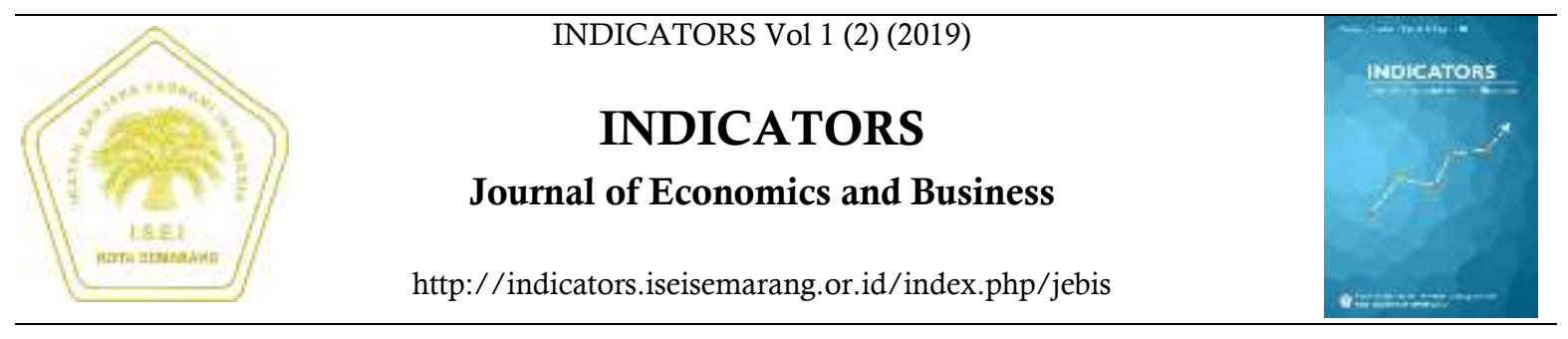

\title{
Efisiensi Pengeluaran Infrastruktur Terhadap Pertumbuhan Industri Kabupaten Cilacap
}

Rochmah Utaria Wiguna, Rr.Retno Sugiharti ${ }^{凶}$

Fakultas Ekonomi, Universitas Tidar

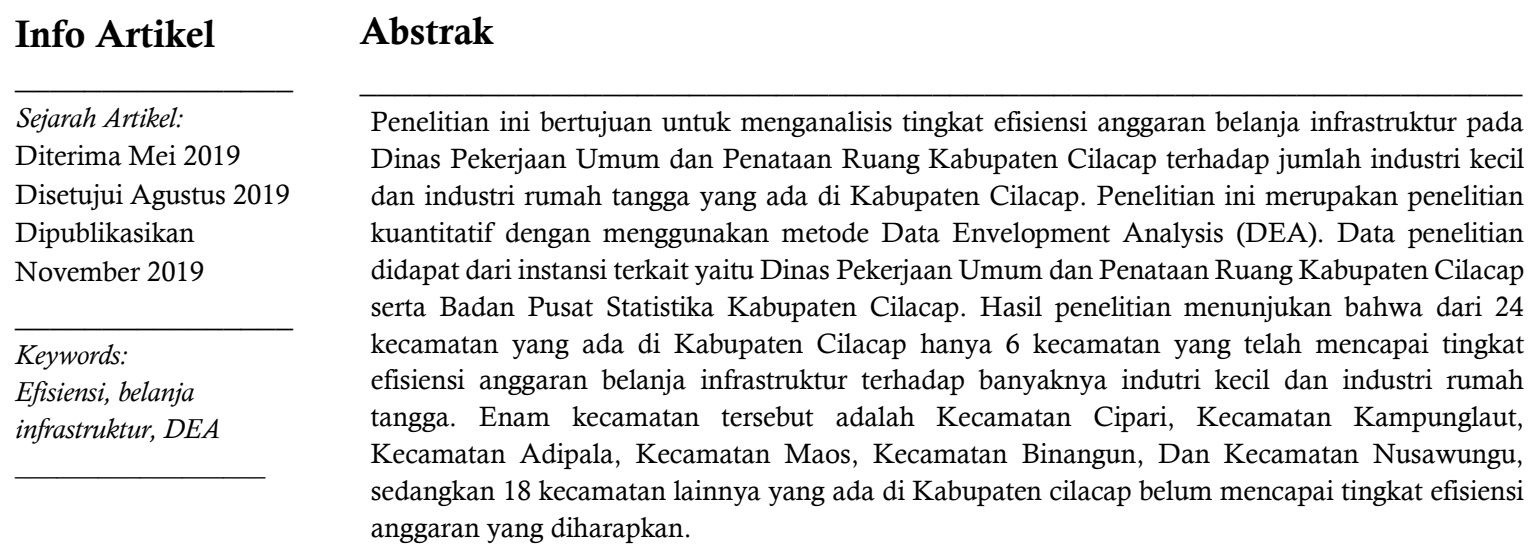

\footnotetext{
${ }^{\bowtie}$ Alamat korespondensi:

Fakultas Ekonomi Universitas Tidar

J1. Kapetn Suparman 39 Potrobangsan, Magelang

E-mail: (retno.sugiharti@untidar.ac.id)
} 


\section{PENDAHULUAN}

Pada dasarnya infrastruktur sebagai wujud investasi yang dilakukan pemerintah merupakan public capital atau modal publik yang terdiri dari jalan umum, jembatan, sistem saluran pembuangan dan lain sebagainya. Infrastruktur merupakan sistem yang dapat mendukung sistem sosial dan sistem ekonomi yang secara sekaligus juga menjadi penghubung sistem lingkungan, yang mana sistem ini dapat digunakan sebagai dasar dalam mengambil kebijakan pemerintah. Pembangunan infrastruktur dicirikan sebagai langkah awal sebuah negara yang akan melalui tahap lepas landas dalam teori tahapan pertumbuhan ekonomi.

Di Indonesia sendiri sejak masa pemerintahan Joko Widodo pembangunan infrastruktur menjadi salah satu hal yang paling sering digaungkan. Pentingnya infrastruktur

dibuat bukan semata-mata menciptakan prasarana sosial yang baik disuatu negara namun dampak pembangunan infrastrukturlah yang akan mendatangkan manfaat lebih baik bagi para pelaku usaha, rumah tangga maupun pemerintah itu sendiri. Pentingnya pembangunan infrastruktur di Indonesia antara lain (1) pembangunan infrastruktur merupakan ajang cipta lapangan kerja, (2) pembangunan infrastruktur sebagai jaringan untuk memperbaiki distribusi logistik dan (3) yang paling penting dengan adanya pembangunan infrastruktur dapat menciptakan pusat-pusat ekonomi baru di berbagai wilayah di Indonesia.

Sejalan dengan hal tersebut pemerintah daerah Kabupaten Cilacap juga terus berbenah diri dalam melaksanakan pembangunan infrastruktur. Hal ini dibuktikan dengan data perkembangan luas jalan di Kabupaten Cilacap sebagai berikut.

Tabel 1

Panjang Jalan Kabupaten Cilacap Menurut Kondisi Jalan 2013-2018

\begin{tabular}{lrrrrrr}
\hline Kondisi & \multicolumn{7}{c}{ Panjang Jalan (km) } \\
\cline { 2 - 7 } Jalan & $\mathbf{2 0 1 3}$ & $\mathbf{2 0 1 4}$ & $\mathbf{2 0 1 5}$ & $\mathbf{2 0 1 6}$ & $\mathbf{2 0 1 7}$ & $\mathbf{2 0 1 8}$ \\
\hline Baik & 644.9 & 624.92 & 612.01 & 732.73 & 744.234 & 745.072 \\
Sedang & 147.81 & 159.3 & 214.17 & 181.62 & 130.530 & 150.780 \\
Rusak & 171.27 & 184.52 & 210.44 & 179.61 & 178.652 & 168.902 \\
Rusak & & & & & & \\
Parah & 217.18 & 212.44 & 250.47 & 193.12 & 233.666 & 204.448 \\
\hline Jumlah & $\mathbf{1 1 8 1 . 1 6}$ & $\mathbf{1 1 8 1 . 1 8}$ & $\mathbf{1 2 8 7 . 0 9}$ & $\mathbf{1 2 8 7 . 0 8}$ & $\mathbf{1 2 8 7 . 0 8 2}$ & $\mathbf{1 2 6 9 . 2 0 2}$ \\
\hline
\end{tabular}

Sumber: BPS Kabupaten Cilacap, 2019

Berdasarkan data diatas dapat disimpulkan bahwa penambahan panjang jalan berkualitas baik meningkat setiap tahunnya, tercatat dari tahun 2013-2018. Pembangunan jalan dalam tipe kondisi jalan dalam keadaan sedang mengalami fluktuasi, sempat mengalami kenaikan jumlah panjang jalan hingga tahun 2015 sebelum akhirnya mengalami penurunan pada tahun berikutnya dan bisa kembali meningkat pada akhir taun 2018. Sedangkan Jalan dengan kondisi rusak memiliki keadaan fluktuasi yang hampir serupa. Terjadi kenaikan dan penurunan jumlah panjang jalan kondisi rusak diperiode 2013-2018. Begitu pula dengan kondisi jalan rusak parah. Terjadinya kenaikan dan penurunan jumlah panjang jalan baik dalam kondisi baik, sedang, rusak, maupun rusak parah mengindikasikan adanya perubahan-perubahan kebijakan pembangunan infrastruktur yang dilakukan oleh pemerintah kabupaten cilacap selama periode 2013-2018. Dengan kata lain kebijakan pemerintah Kabupaten Cilacap nampak belum dapat konsisten terkait dengan pembangunan insfrastruktur . 


\section{TINJAUAN PUSTAKA}

Munculnya pusat-pusat ekonomi baru sebagai dampak positif adanya pembangunan infrastruktur seharusnya meningkat seiring dengan meningkatnya pembangunan infrastruktur seperti jalan, jembatan dan lain sebagainya. Keberadaan infrastruktur ditujukan untuk menciptakan percepatan distribusi barang dan jasa bahan baku produksi untuk sector industri sebagai harapan tumbuhnya pusat ekonomi yang baru. Pentingnya infrastruktur telah dibuktikan oleh Cahyanti \& Anjaningrum (2018) yang meneliti tentang faktor-faktor yang mempengaruhi pertumbuhan usaha kecil sektor industri pengolahan di Kota Malang. Berdasarkan penelitian tersebut diperoleh kesimpulan bahwa pertumbuhan jumlah industri kecil yang terjadi di wilayah Kota Malang dipengaruhi oleh beberapa faktor yang salah satunya adalah kualitas infrastruktur yang tersedia di wilayah tersebut.

Dari penelitian Cahyanti \& Anjaningrum (2018) tersebut, dapat disimpulkan bahwa kualitas infrastruktur jalan akan memberikan manfaat ekonomi secara signifikan bagi wilayah sekitar. Atribut manfaat ekonomi yang dimaksudkan adalah biaya modal usaha, banyaknya usaha dan jumlah aset, serta pendapatan dan tabungan. Hubungan positif antara peningkatan kualitas insfrastruktur jalan dengan kualitas dari manfaat ekonomi yang didapatkan masyarakat begitupun sebaliknya pun dibuktikan oleh NSS, Suryawardana, \& Triyani (2015)

Apabila melihat kasus pada Kabupaten Cilacap, jumlah pertumbuhan industri yang ada di Kabupaten Cilacap tidak sebesar anggaran inftrastruktur yang telah dikeluarkan oleh pemerintah. Untuk tahun 2018 penambahan jumlah industri kecil di masing-masing Kecamatan se-Kabupaten Cilacap sebesar 13 industri padahal dana pembangunan infrastruktur yang telah dikeluarkan pemerintah Kabupaten Cilacap pada tahun 2018 untuk tiap kecamatan sebesar 6,5 milyar rupiah. Walaupun untuk industri rumah tangga cukup baik dengan 34 industri rumah tangga baru berdiri selama tahun 2018. Namun apabila dibandingkan dengan total jumlah tambahan UMK (Usaha Mikro Kecil) baru di wilayah Provinsi Jawa Tengah sebanyak 143.738, kontribusi 34 industri rumah tangga dari Kabupaten Cilacap masih sangat rendah.

Masalah industri di Kabupaten Cilacap memang bukan hanya disebabkan oleh infrastruktur saja namuan dengan banyaknya industri besar nasional berbasis minyak dan gas di Kabupaten Cilacap menjadikan industri kecil dan industri rumah tangga sulit berkembang. Pertumbuhan industri kecil di Kabupaten Cilacap dari tahun ke tahun memang cenderung rendang, sekitar 4 persen \%. Selain itu rendahnya mutu SDM dan penggunaan teknologi tepat guna bidang industri kecil di Kabupaten Cilacap turut menambah buruknya permasalahan industri masyarakat di wilayah ini (Buku RPJMD Kab.Cilacap 2017-2022).

Beberapa fakta diatas menjadi latar belakang dalam penelitian ini. Penelitian ini berfokus pada permasalahan efisiensi anggaran yang digelontorkan oleh pemerintah Kabupaten Cilacap berkenaan dengan pembangunan infrastruktur yang akan memacu pertumbuhan industri kecil dan industri rumah tangga di Kabupaten Cilacap. Masalah efisiensi anggaran ini penting untuk dianalisis karena terkait dengan dasar keefisiensian anggaran yang berlandaskan pada Undang-Undang No. 17 tahun 2003 tentang Keuangan Negara, disebutkan pada pasal 3 ayat 1 bahwa keuangan Negara harus dikelola secara tertib, taat pada peraturan perundang-undangan, efisien, ekonomis, efektif, transparan, dan bertanggung jawab dengan memperhatikan rasa keadilan dan kepatutan sehingga efektifitas dan efisiensi anggaran menjadi dasar dalam pengelolaan keuangan daerah.

Penelitian serupa telah dilakukan oleh berbagai peneliti di berbagai tempat namun hanya beberapa yang menjadikan variabel jumlah industri terutama industri kecil dan industri rumah tangga menjadi variabel output dalam analisis. Hal ini menjadi menarik untuk di analisis karena variabel jumlah industri terutama industri kecil dan industri rumah tangga merupakan masalah yang saat ini dihadapi oleh Kabupaten Cilacap, selain itu efisiensi anggaran menjadi topik yang menarik perhatian karena efisiensi anggaran akan menunjukkan pola kebijakan pemerintah terutama terkait dengan kebijakan keuangan. Penelitian menggunakan DEA untuk menganalisis efisiensi belanja publik telah dilakukan antara lain oleh Rapiuddin \& Rusydi (2017), Kristiyanto \& Widodo (2017), Zulfahmi Pratama, Subagiarta, \& Badjuri (2016), Yanti \& Kustiani (2016), Yunan (2014) dan Pertiwi (2007). Hasil yang robust dan baik yang ditunjukkan oleh penelitian-penelitian tersebut menunjukkan bahwa DEA adalah metode yang cukup baik dalam menganalisis efisiensi khususnya efisiensi anggran. Penelitian serupa telah dilakukan oleh Kementrian Keuangan Republik Indonesia (2011) yang membahas tentang belum tercapaianya tingkat efektivitas dan efisiensi belanja kementrian/lembaga yang berhubungan secara langsung dengan belanja infrastruktur, yaitu Kementrian Pekerjaan Umum, Kementrian Perhubungan dan Kementrian Energi dan Sumber Daya Mineral. Penelitian tersebut menggunakan model analisis DEA, review dan tracking DIPA. 
Hasil penelitian menunjukkan dari 33 provinsi di Indonesia hanya Provinsi Jawa Barat dan Jawa Tengah yang menunjukan tingkat keefisienan anggaran infrastruktur yang paling tinggi, sedangkan tingkat efisiensian anggaran infrastruktur paling rendah adalah provinsi Papua Barat dan DKI Jakarta. Solusi dari permasalahan ketidak efisiensian ini adalah meningkatkan kualitas struktur pengalokasian anggaran, dan menigkatkan dan menyeimbangkan pola penyerapan anggaran.

Dian Merini (2013) dalam penelitiannya yang berjudul "Analisis Efisiensi Pengeluaran Pemerintah Sektor Publik Di Kawasan Asia Tenggara: Aplikasi Data Envelopment Analysis" meneliti tentang tingkat efisien pengeluaran sektor publik di negara-negara Asia Tenggara terhadap indikator output berupa kesejahteraan masyarakat, pendidikan, dan kesehatan. Dari penelitian ini diperoleh kesimpulan bahwa di wilayah Asia Tenggara, Singapura menjadi negara dengan tingkat efisiensi tertinggi, sedangkan Malaysia mengalami inefisiensi pengeluaran publik yang paling parah. NegaraNegara dengan penghasilan di tingkat menengah keatas seperti Malaysia, Brunei Darussalam, Thailand, dan Vietnam cenderung memiliki tingkat pengeluaran sektor publik yang tinggi maka dari itu kecenderungan ketidak efisienan anggaran sangat mungkin terjadi. Sedangkan untuk negara miskin atau berpenghasilan di tingkat bawah seperti Kamboja dan Laos meski memiliki derajat efisiensi anggaran lebih tinggi, namun pada kenyataannya memiliki tingkat layanan publik yang paling buruk.

\section{METODE PENELITIAN}

Penelitian ini adalah penelitian dengan jenis kuantitatif dengan data yang digunakan adalah data belanja jalan, jembatan dan bangunan yang dilakukan oleh Dinas Pekerjaan Umum Dan Penataan Ruang Kabuaten Cilacap pada tahun 2017-2018. Untuk kebutuhan penelitian maka masing-masing belanja dikelompokkan ke dalam 24 Kecamatan yang ada di Kabupaten Cilacap. Data ini tersebut didapatkan dari dokumen Laporan Pengawasan Anggaran Definitif Per Kegiatan Dinas Pekerjaan Umum dan Penataan Ruang Kabupaten Cilacap tahun 2017 dan 2018. Data lain yang digunakan adalah data jumlah indutri kecil dan industri rumah tangga yang didapatkan dari BPS Kabupaten Cilacap.

Dalam menganalisis data-data tersebut peneliti menggunakan metode analisis non parametrik yaitu metode Data Envelopment Analisys (DEA). DEA merupakan prosedur yang didesain relatif untuk suatu Unit Kegiatan Ekonomi (UKE) yang menggunakan beberapa input dan beberapa output (multi-input multioutput) dimana penggabungan input \& output tersebut sebenarnya tidak mungkin dilakukan. Input dalam penelitian ini berupa belanja jalan, belanja jembatan, dan belanja bangunan yang dilakukan Dinas Pekerjaan Umum Dan Penataan Ruang Kabupaten Cilacap. Sedangkan output yang digunakan adalah jumlah industri kecil dan industri rumah tangga yang ada di Kabupaten Cilacap.

Dalam DEA, efisiensi relatif Unit Kegiatan Ekonomi atau (UKE) didefinisikan sebagai rasio dari total output tertimbang yang dibagi dengan total input tertimbangnya ( Total Weighted Output / Total Weighted Input). Inti dari DEA adalah menentukan bobot (weights) untuk setiap input dan output UKE. Bobot tersebut memiliki 2 sifat yaitu pertama tidak bernilai negatif, dan ke-dua bersifat universal, artinya setiap UKE dalam sampel harus dapat menggunakan seperangkat bobot yang sama untuk mengevaluasi rasionya (total weighted output/total weighted input) dan rasio tersebut tidak boleh lebih dari 1 ( total weighted output/total weighted input $\leq 1$ ).

Asumsi pada DEA adalah bahwa setiap UKE akan memiliki bobot (maximize total weighted output/total weighted input), karena setiap UKE menggunakan kombinasi input yang berbeda untuk menghasilkan kombinasi output yang berbeda pula, maka setiap UKE akan memilih seperangkat bobot yang mencerminkan keragaman tersebut. Secara umum UKE akan menetapkan bobot yang tinggi untuk input yang penggunaannya sedikit dan untuk output yang diproduksi dengan banyak. Bobot-bobot tersebut bukan merupakan nilai ekonomis dari input dan outputnya, melainkan sebagai penentu untuk memaksimumkan efisiensi dari suatu UKE (Pertiwi, 2007). DEA dapat menangani beberapa jenis permasalahan seperti permasalahan input dan output yang berbeda jenisnya dalam waktu yang bersamaan, selain itu dengan DEA tidak diperlukan penggunaan asumsi khusus untuk masing-masing input dan output yang 
digunakan. Analisis DEA akan memberikan peringkat efisiensi berdasarkan data numerik dalam arti hasil analisis DEA tidak menggunakan opini subjektif. Asumsi yang digunakan adalah output oriented dimana variabel input (belanja jalan, belanja jembatan, dan belanja bangunan) dianggap telah maksimal / optimum karena dianggap adanya keterbatasan anggaran dana yang dimiliki pemerintah, sedangkan output (jumalah industri kecil dan industri rumah tangga) yang dihasilkan harus bisa semaksimal mungkin. Maka dari itu penelitian ini juga dapat menentukan jumlah output yang harus tercipta agar terjadi efisiensi anggaaran pemerintah yang telah dikeluarkan melalui nilai radial movement.

\section{HASIL DAN PEMBAHASAN}

Hasil pengolahan DEA diperoleh nilai CRSTE dan VRSTA. Nilai CRSTE (Constan
Return to Scale Technical Efficiency) menunjukan nilai efisiensi skala yang diartikan sebagai standard efisiensi yang mengasumsikan bahwa semua komponen unit kegiatan ekonomi berada dalam keadaan yang optimum tanpa adanya kendala. Sedangkan nilai VRSTE menunjukan nilai dari skala teknis. VRSTE (Variable Return to Scale Technical Efficiency) diartikan sebagai nilai efisiensi teknis yang menggunakan asumsi bahwa tiap unit kegiatan ekonomi yang ada dalam model memiliki keadaan yang berbeda-beda karena memiliki keterbatasan-keterbatasan masing-masing region dan masing-masing variabel pula baik input maupun output. Model VRSTE dipilih karena masing-masing kecamatan yang ada di Kabupaten Cilacap memiliki karakteristik yang berbeda maka diasumsikan pula unit kegiatan ekonomi yang digunakan berbeda. Analisis DEA dilakukan menggunakan software DEAP v.21.

Tabel 1 Hasil Uji Efisiensi Anggaran Belanja Infrastruktur Terhadap Jumlah Industri Kecil Dan Industri Rumah Tangga Di Kabupaten Cilacap Tahun 2017-2018 Menggunakan Analisis DEA

\begin{tabular}{rllrrr}
\hline \multirow{2}{*}{ NO } & \multirow{2}{*}{ REGION } & \multirow{2}{*}{ CRSTE } & VRSTE & \multicolumn{2}{c}{ RM } \\
\cline { 5 - 6 } & & & & OUTPUT 1 & OUTPUT 2 \\
\hline 1 & Dayeuhluhur & 0.262 & 0.510 & 236.117 & 898.395 \\
2 & Wanareja & 0.176 & 0.330 & 109.417 & 8056.317 \\
3 & Majenang & 0.237 & 0.513 & 209.109 & 3123.333 \\
4 & Cimanggu & 0.465 & 0.809 & 81.84 & 1227.597 \\
5 & Karangpucung & 0.303 & 0.534 & 217.935 & 1424.42 \\
6 & Cipari & 0.963 & 1.000 & 0 & 0 \\
7 & Sidareja & 0.167 & 0.330 & 272.048 & 5627.732 \\
8 & Kedungreja & 0.390 & 0.581 & 103.083 & 339.528 \\
9 & Patimuan & 0.300 & 0.901 & 47.983 & 157.015 \\
10 & Gandrungmangu & 0.524 & 0.657 & 146.939 & 769.087 \\
11 & Bantarsari & 0.182 & 0.320 & 212.646 & 6749.38 \\
12 & Kawunganten & 0.162 & 0.584 & 167.357 & 3626.298 \\
13 & Kampunglaut & 1.000 & 1.000 & 0 & 0 \\
14 & Jeruklegi & 0.501 & 0.973 & 0.22 & 182.477 \\
15 & Kesugihan & 0.077 & 0.224 & 13.883 & 8319.414 \\
16 & Adipala & 1.000 & 1.000 & 0 & 0 \\
17 & Maos & 1.000 & 1.000 & 0 & 0 \\
18 & Sampang & 0.439 & 0.464 & 65.752 & 762.954 \\
19 & Kroya & 0.443 & 0.539 & 112.927 & 4077.341 \\
20 & Binangun & 1.000 & 1.000 & 0 & 0 \\
21 & Nusawungu & 1.000 & 1.000 & 0 & 0 \\
& & & & &
\end{tabular}




\begin{tabular}{cccccc}
\hline \multirow{2}{*}{ NO } & \multirow{2}{*}{ REGION } & \multirow{2}{*}{ CRSTE } & \multirow{2}{*}{ VRSTE } & \multicolumn{2}{c}{ RM } \\
\cline { 5 - 6 } & & & & OUTPUT 1 & OUTPUT 2 \\
\hline 22 & Cilacap Selatan & 0.454 & 0.464 & 136.529 & 844.627 \\
23 & Cilacap Tengah & 0.337 & 0.624 & 181.771 & 635.597 \\
24 & Cilacap Utara & 0.324 & 0.766 & 41.583 & 449.468 \\
\hline & MEAN & 0.488 & 0.672 & - & - \\
\hline
\end{tabular}

Sumber : Hasil olah DEAP v2.1

Berdasarkan tabel diatas maka dapat disimpulkan sebagai berikut:

Kecamatan Dayeuhluhur memiliki nilai CRSTE sebesar $0.262<1$ dan nilai VRSTE sebesar $0.510<1$ maka dikatakan kecamatan Dayeuhluhur belum mencapai tingkat efisiensi anggaran belanja infrastruktur jalan jembatan dan bangunan terhadap jumlah indutri kecil dan industri rumah tangga untuk periode 2017-2018, baik efisiensi secara skala maupun efisiensi secara teknis. Pada kolom RM (Radial Movement) Kecamatan Dayeuhluhur untuk output 1 bernilai 236,117 dan output 2 bernilai 898,295 berarti apabila Kecamatan Dayeuhluhur ingin mencapai tingkat efisiensi anggaran maka kecamatan ini harus mendirikan industri kecil baru sebanyak 236 dan industri rumah tangga sebanyak 898.

Kecamatan Wanareja memiliki nilai CRSTE sebesar $0.176<1$ dan nilai VRSTE sebesar $0.330<1$ maka dikatakan Kecamatan Wanareja belum mencapai tingkat efisiensi anggaran belanja infrastruktur jalan,jembatan dan bangunan terhadap jumlah indutri kecil dan industri rumah tangga untuk periode 2017-2018, baik efisiensi secara skala maupun efisiensi secara teknis. Pada kolom RM (Radial Movement) Kecamatan Wanareja untuk output 1 bernilai 109,417 dan output 2 bernilai 8056,317 berarti apabila Kecamatan Wanareja ingin mencapai tingkat efisiensi anggaran maka kecamatan ini harus mendirikan industri kecil baru sebanyak 109 dan industri rumah tangga sebanyak 8056.

Kecamatan Majenang memiliki nilai CRSTE sebesar $0.237<1$ dan nilai VRSTE sebesar $0.513<1$ maka dikatakan Kecamatan Majenang belum mencapai tingkat efisiensi anggaran belanja infrastruktur jalan,jembatan dan bangunan terhadap jumlah indutri kecil dan industri rumah tangga untuk periode 2017-2018, baik efisiensi secara skala maupun efisiensi secara teknis. Pada kolom RM (Radial Movement) Kecamatan Majenang untuk output 1 bernilai 209,109 dan output 2 bernilai 3123,333 berarti apabila Kecamatan Majenang ingin mencapai tingkat efisiensi anggaran maka kecamatan ini harus mendirikan industri kecil baru sebanyak 209 dan industri rumah tangga sebanyak 3123 .

Kecamatan Cimanggu memiliki nilai CRSTE sebesar $0.465<1$ dan nilai VRSTE sebesar $0.809<1$ maka dikatakan Kecamatan Cimanggu belum mencapai tingkat efisiensi anggaran belanja infrastruktur jalan,jembatan dan bangunan terhadap jumlah indutri kecil dan industri rumah tangga untuk periode 2017-2018, baik efisiensi secara skala maupun efisiensi secara teknis. Pada kolom RM (Radial Movement) Kecamatan Cimanggu untuk output 1 bernilai 81,84 dan output 2 bernilai 1227,597 berarti apabila Kecamatan Cimanggu ingin mencapai tingkat efisiensi anggaran maka kecamatan ini harus mendirikan industri kecil baru sebanyak 82 dan industri rumah tangga sebanyak 1228.

Kecamatan Karangpucung memiliki nilai CRSTE sebesar $0.303<1$ dan nilai VRSTE sebesar $0.534<1$ maka dikatakan Kecamatan Karangpucung belum mencapai tingkat efisiensi anggaran belanja infrastruktur jalan,jembatan dan bangunan terhadap jumlah indutri kecil dan industri rumah tangga untuk periode 2017-2018, baik efisiensi secara skala maupun efisiensi secara teknis. Pada kolom RM (Radial Movement) Kecamatan Karangpucung untuk output 1 bernilai 217,935 dan output 2 bernilai 1424,420 berarti apabila Kecamatan Karangpucung ingin mencapai tingkat efisiensi anggaran maka kecamatan ini harus mendirikan 
industri kecil baru sebanyak 2018 dan industri rumah tangga sebanyak 1424.

Kecamatan Cipari memiliki nilai CRSTE sebesar $0.963<1$ maka dari itu secara sekala belanja infrastruktur yang dilakukan pemerintah Kabupaten Cilacap di Kecamatan Cipari untuk periode 2017-2018, belum mencapai tingkat efisiensi terhadap jumlah industri kecil dan indutri rumah tangga yang ada di Kecamatan Cipari. Namun secara teknis karena nilai VRSTE sebesar 1 maka dikatakan di Kecamatan Cipari anggaran belanja infrastruktur jalan jembatan dan bangunan telah efisien terhadap jumlah indutri kecil dan industri rumah tangga untuk periode 2017-2018.

Kecamatan Sidareja memiliki nilai CRSTE sebesar $0.167<1$ dan nilai VRSTE sebesar $0.330<1$ maka dikatakan Kecamatan Sidareja belum mencapai tingkat efisiensi anggaran belanja infrastruktur jalan,jembatan dan bangunan terhadap jumlah indutri kecil dan industri rumah tangga untuk periode 2017-2018, baik efisiensi secara skala maupun efisiensi secara teknis. Pada kolom RM (Radial Movement) Kecamatan Sidareja untuk output 1 bernilai 272,048 dan output 2 bernilai 5627.732 berarti apabila Kecamatan Sidareja ingin mencapai tingkat efisiensi anggaran maka kecamatan ini harus mendirikan industri kecil baru sebanyak 272 dan industri rumah tangga sebanyak 5628.

Kecamatan Kedungreja memiliki nilai CRSTE sebesar $0.390<1$ dan nilai VRSTE sebesar $0.581<1$ maka dikatakan Kecamatan Kedungreja belum mencapai tingkat efisiensi anggaran belanja infrastruktur jalan,jembatan dan bangunan terhadap jumlah indutri kecil dan industri rumah tangga untuk periode 2017-2018, baik efisiensi secara skala maupun efisiensi secara teknis. Pada kolom RM (Radial Movement) Kecamatan Kedungreja untuk output 1 bernilai 103,083 dan output 2 bernilai 339,528 berarti apabila Kecamatan Kedungreja ingin mencapai tingkat efisiensi anggaran maka kecamatan ini harus mendirikan industri kecil baru sebanyak 103 dan industri rumah tangga sebanyak 340.

Kecamatan Patimuan memiliki nilai CRSTE sebesar $0.300<1$ dan nilai VRSTE sebesar $0.901<1$ maka dikatakan Kecamatan Patimuan belum mencapai tingkat efisiensi anggaran belanja infrastruktur jalan,jembatan dan bangunan terhadap jumlah indutri kecil dan industri rumah tangga untuk periode 2017-2018, baik efisiensi secara skala maupun efisiensi secara teknis. Pada kolom RM (Radial Movement) Kecamatan Patimuan untuk output 1 bernilai 47,983 dan output 2 bernilai 157,015 berarti apabila kecamatan Patimuan ingin mencapai tingkat efisiensi anggaran maka kecamatan ini harus mendirikan industri kecil baru sebanyak 48 dan industri rumah tangga sebanyak 157.

Kecamatan Gandrungmangu memiliki nilai CRSTE sebesar $0.524<1$ dan nilai VRSTE sebesar $0.657<1$ maka dikatakan Kecamatan Gandrungmangu belum mencapai tingkat efisiensi anggaran belanja infrastruktur jalan,jembatan dan bangunan terhadap jumlah indutri kecil dan industri rumah tangga untuk periode 2017-2018, baik efisiensi secara skala maupun efisiensi secara teknis. Pada kolom RM (Radial Movement) Kecamatan Gandrungmangu untuk output 1 bernilai 146,939 dan output 2 bernilai 769,087 berarti apabila Kecamatan Gandrungmangu ingin mencapai tingkat efisiensi anggaran maka kecamatan ini harus mendirikan industri kecil baru sebanyak 147 dan industri rumah tangga sebanyak 769 .

Kecamatan Bantarsari memiliki nilai CRSTE sebesar $0.182<1$ dan nilai VRSTE sebesar $0.320<1$ maka dikatakan Kecamatan Bantarsari belum mencapai tingkat efisiensi anggaran belanja infrastruktur jalan,jembatan dan bangunan terhadap jumlah indutri kecil dan industri rumah tangga untuk periode 2017-2018, baik efisiensi secara skala maupun efisiensi secara teknis. Pada kolom RM (Radial Movement) Kecamatan Bantarsari untuk output 1 bernilai 212,646 dan output 2 bernilai 6749,38 berarti apabila Kecamatan Bantarsari ingin mencapai tingkat efisiensi anggaran maka kecamatan ini harus mendirikan industri kecil baru sebanyak 213 dan industri rumah tangga sebanyak 6749 .

Kecamatan Kawunganten memiliki nilai CRSTE sebesar $0.162<1$ dan nilai VRSTE sebesar $0.584<1$ maka dikatakan Kecamatan 
Kawunganten belum mencapai tingkat efisiensi anggaran belanja infrastruktur jalan,jembatan dan bangunan terhadap jumlah indutri kecil dan industri rumah tangga untuk periode 2017-2018, baik efisiensi secara skala maupun efisiensi secara teknis. Pada kolom RM (Radial Movement) Kecamatan Kawunganten untuk output 1 bernilai 167,357 dan output 2 bernilai 3626,298 berarti apabila Kecamatan Kawunganten ingin mencapai tingkat efisiensi anggaran maka kecamatan ini harus mendirikan industri kecil baru sebanyak 167 dan industri rumah tangga sebanyak 3626.

Kecamatan Kampung laut berdasarkan pengujian memiliki nilai CRSTE sebasar 1 dan nilai VRSTE sebesar 1, ini berarti bahwa Kecamatan Kampunglaut telah mencapai tingkat efisiensi baik secara skala maupun secara teknis. Berarti anggaran belanja infrastruktur jalan, jembatan, dan bangunan yang dilakukan oleh Pemerintah Kabupaten Cilacap di wilayah Kecamatan Kampunglaut telah efisien terhadap jumlah industri kecil dan industri rumah tangga yang ada di kecamatan tersebut untuk periode 2017-2018.

Kecamatan Jeruklegi memiliki nilai CRSTE sebesar $0.501<1$ dan nilai VRSTE sebesar $0.973<1$ maka dikatakan Kecamatan Jeruklegi belum mencapai tingkat efisiensi anggaran belanja infrastruktur jalan,jembatan dan bangunan terhadap jumlah indutri kecil dan industri rumah tangga untuk periode 2017-2018, baik efisiensi secara skala maupun efisiensi secara teknis. Pada kolom RM (Radial Movement) Kecamatan Jeruklegi untuk output 1 bernilai 0.22 dan output 2 bernilai 182,477 berarti apabila Kecamatan Jeruklegi ingin mencapai tingkat efisiensi anggaran maka kecamatan ini harus mendirikan industri kecil baru sebanyak 1 dan industri rumah tangga sebanyak 182.

Kecamatan Kesugihan memiliki nilai CRSTE sebesar $0.077<1$ dan nilai VRSTE sebesar $0.224<1$ maka dikatakan Kecamatan Kesugihan belum mencapai tingkat efisiensi anggaran belanja infrastruktur jalan,jembatan dan bangunan terhadap jumlah indutri kecil dan industri rumah tangga untuk periode 2017-2018, baik efisiensi secara skala maupun efisiensi secara teknis. Pada kolom RM (Radial
Movement) Kecamatan Kesugihan untuk output 1 bernilai 13,883 dan output 2 bernilai 8319,414 berarti apabila Kecamatan Kesugihan ingin mencapai tingkat efisiensi anggaran maka kecamatan ini harus mendirikan industri kecil baru sebanyak 14 dan industri rumah tangga sebanyak 8319

Kecamatan Adipala berdasarkan pengujian memiliki nilai CRSTE sebasar 1 dan nilai VRSTE sebesar 1, ini berarti bahwa Kecamatan Adipala telah mencapai tingkat efisiensi baik secara skala maupun secara teknis. Berarti anggaran belanja infrastruktur jalan, jembatan, dan bangunan yang dilakukan oleh Pemerintah Kabupaten Cilacap di wilayah Kecamatan Adipala telah efisien terhadap jumlah industri kecil dan industri rumah tangga yang ada di kecamatan tersebut untuk periode 2017-2018.

Kecamatan Maos berdasarkan pengujian memiliki nilai CRSTE sebasar 1 dan nilai VRSTE sebesar 1, ini berarti bahw kecamatan Maos telah mencapai tingkat efisiensi baik secara skala maupun secara teknis. Berarti anggaran belanja infrastruktur jalan, jembatan, dan bangunan yang dilakukan oleh Pemerintah Kabupaten Cilacap di wilayah Kecamatan Maos telah efisien terhadap jumlah industri kecil dan industri rumah tangga yang ada di kecamatan Maos untuk periode 2017-2018.

Kecamatan Sampang memiliki nilai CRSTE sebesar $0.439<1$ dan nilai VRSTE sebesar $0.464<1$ maka dikatakan Kecamatan Sampang belum mencapai tingkat efisiensi anggaran belanja infrastruktur jalan,jembatan dan bangunan terhadap jumlah indutri kecil dan industri rumah tangga untuk periode 2017-2018, baik efisiensi secara skala maupun efisiensi secara teknis. Pada kolom RM (Radial Movement) Kecamatan Sampang untuk output 1 bernilai 65,752 dan output 2 bernilai 762,954 berarti apabila Kecamatan Sampang ingin mencapai tingkat efisiensi anggaran maka kecamatan ini harus mendirikan industri kecil baru sebanyak 66 dan industri rumah tangga sebanyak 763.

Kecamatan Kroya memiliki nilai CRSTE sebesar $0.443<1$ dan nilai VRSTE sebesar 0.539 $<1$ maka dikatakan Kecamatan Kroya belum 
mencapai tingkat efisiensi anggaran belanja infrastruktur jalan,jembatan dan bangunan terhadap jumlah indutri kecil dan industri rumah tangga untuk periode 2017-2018, baik efisiensi secara skala maupun efisiensi secara teknis. Pada kolom RM (Radial Movement) Kecamatan Kroya untuk output 1 bernilai 112,927 dan output 2 bernilai 4077,341 berarti apabila Kecamatan Kroya ingin mencapai tingkat efisiensi anggaran maka kecamatan ini harus mendirikan industri kecil baru sebanyak 113 dan industri rumah tangga sebanyak 4077.

Kecamatan Binangun berdasarkan pengujian memiliki nilai CRSTE sebasar 1 dan nilai VRSTE sebesar 1, ini berarti bahwa Kecamatan Binangun telah mencapai tingkat efisiensi baik secara skala maupun secara teknis. Berarti anggaran belanja infrastruktur jalan, jembatan, dan bangunan yang dilakukan oleh Pemerintah Kabupaten Cilacap di wilayah Kecamatan Binangun telah efisien terhadap jumlah industri kecil dan industri rumah tangga yang ada di Kecamatan Binangun untuk periode 2017-2018.

Kecamatan Nusawungu berdasarkan pengujian memiliki nilai CRSTE sebasar 1 dan nilai VRSTE sebesar 1, ini berarti bahwa Kecamatan Nusawungu telah mencapai tingkat efisiensi baik secara skala maupun secara teknis. Berarti anggaran belanja infrastruktur jalan, jembatan, dan bangunan yang dilakukan oleh Pemerintah Kabupaten Cilacap di wilayah Kecamatan Nusawungu telah efisien terhadap jumlah industri kecil dan industri rumah tangga yang ada di Kecamatan Nusawungu untuk periode 2017-2018.

Kecamatan Cilacap Selatan memiliki nilai CRSTE sebesar $0.454<1$ dan nilai VRSTE sebesar $0.464<1$ maka dikatakan Kecamatan Cilacap Selatan belum mencapai tingkat efisiensi anggaran belanja infrastruktur jalan,jembatan dan bangunan terhadap jumlah indutri kecil dan industri rumah tangga untuk periode 2017-2018, baik efisiensi secara skala maupun efisiensi secara teknis. Pada kolom RM (Radial Movement) Kecamatan Cilacap Selatan untuk output 1 bernilai 136,529 dan output 2 bernilai 844,627 berarti apabila Kecamatan Cilacap Selatan ingin mencapai tingkat efisiensi anggaran maka kecamatan ini harus mendirikan industri kecil baru sebanyak 137 dan industri rumah tangga sebanyak 845 .

Kecamatan Cilacap Tengah memiliki nilai CRSTE sebesar $0.337<1$ dan nilai VRSTE sebesar $0.624<1$ maka dikatakan Kecamatan Cilacap Tengah belum mencapai tingkat efisiensi anggaran belanja infrastruktur jalan,jembatan dan bangunan terhadap jumlah indutri kecil dan industri rumah tangga untuk periode 2017-2018, baik efisiensi secara skala maupun efisiensi secara teknis. Pada kolom RM (Radial Movement) Kecamatan Cilacap Tengah untuk output 1 bernilai 181,771 dan output 2 bernilai 635,627 berarti apabila Kecamatan Cilacap Tengah ingin mencapai tingkat efisiensi anggaran maka kecamatan ini harus mendirikan industri kecil baru sebanyak 182 dan industri rumah tangga sebanyak 636 .

Kecamatan Cilacap Utara memiliki nilai CRSTE sebesar $0.324<1$ dan nilai VRSTE sebesar $0.766<1$ maka dikatakan Kecamatan Cilacap Utara belum mencapai tingkat efisiensi anggaran belanja infrastruktur jalan,jembatan dan bangunan terhadap jumlah indutri kecil dan industri rumah tangga untuk periode 2017-2018, baik efisiensi secara skala maupun efisiensi secara teknis. Pada kolom RM (Radial Movement) Kecamatan Cilacap Utara untuk output 1 bernilai 41,583 dan output 2 bernilai 449,468 berarti apabila Kecamatan Cilacap Tengah ingin mencapai tingkat efisiensi anggaran maka kecamatan ini harus mendirikan industri kecil baru sebanyak 42 dan industri rumah tangga sebanyak 449 .

Berdarakan nilai rata-rata nilai CRSTE sebesar $0,488<1$ dan nilai rata-rata VRSTE sebesar $0.672<1$ berarti rata-rata kecamatan di Kabupaten Cilacap memang belum mencapai tingkat efisiensi anggaran belanja infrastruktur jalan jembatan dan bangunan terhadapa jumlah industri kecil dan industri rumah tangga baik efisien secara skala maupun efisien secara teknis untuk periode 2017-2018.

Berdasarkan metode VRSTE (Variable Return to Scale Technical Efficiency) Kecamatan Kesugihan menjadi kecamatan dengan tingkat efisiensi anggaran belanja infrastruktur terendah dibanding 23 kecamatan 
lain yang ada di Kabupaten Cilacap untuk periode 2017-2018. Berdasarkan metode VRSTE (Variable Return to Scale Technical Efficiency) Kecamatan Kesugihan menjadi kecamatan dengan tingkat efisiensi anggaran belanja infrastruktur terendah dibanding 23 kecamatan lain yang ada di Kabupaten Cilacap untuk periode 2017-2018.

Berdasarkan metode CRSTE (Constan Return to Scale Technical Efficiency) Kecamatan Wanareja menjadi kecamatan dengan tingkat efisiensi anggran belanja infrastruktur terendah dibanding 23 kecamatan lain yang ada di Kabupaten Cilacap untuk periode 2017-2018.

\section{SIMPULAN}

Berdasarkan hasil uji efisiensi menggunakan Data Envelopment Analisys dengan asumsi output oriented maka dari 24 kecamatan yang ada di Kabupaten Cilacap hanya 6 kecamatan yang telah mencapai tingkat efisiensi anggaran belanja infrastruktur terhadap banyaknya indutri kecil dan industri rumah tangga. Enam kecamatan tersebut adalah Kecamatan Cipari, Kecamatan Kampunglaut, Kecamatan Adipala, Kecamatan Maos, Kecamatan Binangun, Dan Kecamatan Nusawungu, sedangkan 18 kecamatan lainnya yang ada di Kabupaten Cilacap belum mencapai tingkat efisiensi anggaran. Dikatakan belum mencapai tingkat efisiensi dikarenakan jumlah output berupa industri kecil dan industri rumah tangga yang tersedia di suatu kecamatan belum sebanding dengan nilai proyek pembangunan infrastruktur berupa jalan, jembatan, dan bangunan yang dilakukan Dinas Pekerjaan Umum dan Penataan Ruang Kabupaten Cilacap.

Penelitian ini merupakan penelitian dasar dimana peneliti hanya melihat tingkat efisiensi atau inefisiensi dari adanya input terhadap output yang diujikan. Maka dari itu penelitian ini sangat mungkin untuk dilakukan penelitianpenelitian berikutnya yang berhubungan dengan efisiensi anggaran pembangunan infrastruktur terhadap output-output lainnya atau mengkaji faktor-faktor apa saja yang dapat mendorong peningkatan jumlah industri di wilayah
Kabupaten Cilacap. Beberapa keterbatasan dalam penelitian ini antara lain tidak faktorfaktor lain penentu pertumbuhan jumlah industri kecil dan rumah tangga yang ada di Kabupaten Cilacap, hanya mengambil data pembangunan infrastruktur yang dilakukan oleh Dinas Pekerjaan Umum Dan Penataan Ruang Kabupaten Cilacap, diharapkan keterbatasan ini dapat diakomodasi pada penelitian selanjutnya.

\section{DAFTAR PUSTAKA}

Cahyanti, M. M., \& Anjaningrum, W. D. (2018). Faktor-Faktor Yang Mempengaruhi Perkembangan Usaha Kecil Sektor Industri Pengolahan Di Kota Malang. Jurnal Ilmiah Bisnis Dan Ekonomi Asia, 11(2), 73-79. https://doi.org/10.32812/jibeka.v11i2.50

Dian Merini. (2013). Analisa Efisiensi Pengeluaran Pemerintah Sektor Publik di Kawasan Asia Tenggara: Aplikasi Data Envelopment Analysis. Working Paper Universitas Brawijaya, 1-31.

Kristiyanto, S., \& Widodo, S. (2017). Analisis Efisiensi Belanja Langsung Dan Tidak Langsung Pemerintah Kabupaten Kota Di Jawa Timur Dalam Pengentasan Kemiskinan. Jurnal Ilmu Ekonomi Dan Pembangunan, 17(1), 1-12.

NSS, R. L. P., Suryawardana, E., \& Triyani, D. (2015). Analisis Dampak Pembangunan Infrastruktur Jalan Terhadap Pertumbuhan Usaha Ekonomi Rakyat Di Kota Semarang. Jurnal Dinamika Sosial Budaya, 17(1), 82. https://doi.org/10.26623/jdsb.v17i1.505

Pertiwi, L. D. (2007). Efisiensi Pengeluaran Pemerintah Daerah di Proponsi Jawa Tengah. Jurnal Ekonomi Pembangunan, 12(2), 123-139.

Rapiuddin, R., \& Rusydi, B. U. (2017). Efisiensi Belanja Pemerintah Sektor Pendidikan dan Kesehatan di Provinsi Sulawesi Selatan. EcceS (Economics, Social, and Development Studies), 4(1), 23. https://doi.org/10.24252/ecc.v4i1.3344

Yanti, P., \& Kustiani, N. A. (2016). Analisis Efisiensi Belanja Daerah Urusan Kesehatan dengan Metode Data Envelopment Analysis (DEA): Studi Pada Pemerintah Kabupaten / Kota di Provinsi Banten. Jurnal Info Artha, 4, 81-96. https://doi.org/10.31092/jia.v4i4.49 
Yunan, Z. Y. (2014). Tingkat Efisiensi Pengeluaran Pemerintah Daerah Di Pulau Jawa. Signifikan: Jurnal Ilmu Ekonomi, 3(1). https://doi.org/10.15408/sigf.v3i1.2053

Zulfahmi Pratama, Subagiarta, I. W., \& Badjuri. (2016). Analisis Efisiensi Pengeluaran Pemerintah Daerah Di Provinsi Jawa Timur Dengan Pendekatan Data Envelopment Analysis (DEA). Artikel Ilmiah Mahasiswa 2016. Retrieved

from http://repository.unej.ac.id/handle/123456789 $/ 76387$ 